\title{
Physical-technical prior competencies of engineering students
}

\author{
Stefan Behrendt ${ }^{1 *}$, Elmar Dammann $^{1 *}$, Florina Ștefănică $^{1 *}$, Bernd Markert $^{2 \dagger}$ and Reinhold Nickolaus ${ }^{1 \dagger}$
}

\author{
* Correspondence: \\ behrendt@bwt.uni-stuttgart.de; \\ dammann@bwt.uni-stuttgart.de; \\ stefanica@bwt.uni-stuttgart.de \\ ${ }^{\dagger}$ Equal contributors \\ ${ }^{1}$ Institute of Education, Department \\ of Vocational, Economic and \\ Technical Education, University of \\ Stuttgart, Geschwister-Scholl-Str. \\ 24D, Stuttgart 70174, Germany \\ Full list of author information is \\ available at the end of the article
}

\begin{abstract}
Background: This article addresses the question of which physical-technical prior competencies students in Germany start their engineering studies with. Furthermore, it analyzes the influence of e.g. formal qualifications, curricular weights in school, or participation in preparatory courses on these prior competencies.

Methods: Using a sample of 2345 students, we modelled the structure of competencies and conducted proficiency scaling. Furthermore, we computed t-tests and analyses of variance in order to analyze the physical-technical prior competencies' dependency on education biographies, gender, participation in propaedeutic courses etc.

Results: Our results reveal a three-dimensional structure for the physical-technical prior competencies as most suitable. Additionally, we find a big variance in the physicaltechnical prior competencies. Students with a general entrance qualification, male students, students attending universities, students having had many physics lessons in school and students having participated in preparatory courses in physics achieve better results.

Conclusions: Summing up, the results of our survey reveal a big variance in the physical-technical prior competencies. Hence, we find a substantial proportion of freshmen with significant competency deficits. We assume that these competency deficits constitute a factor which makes (the beginning of) engineering studies more difficult.
\end{abstract}

\section{Background}

Numerous preparatory courses are currently offered for engineering studies. These courses aim at closing students' knowledge gaps and creating sufficiently solid contentrelated bases for successfully mastering studies. Offers on mathematical knowledge and abilities are especially widespread (e.g. Bausch et al. 2014). There is strong evidence for the fact that prior competencies have a great influence on the development of competencies within the course of studies (e.g. Hell et al. 2007). It is however unclear (a) which competencies students really have in the beginning of their studies and (b) to which extent gender, type of institution of higher education, course of studies, information on the type of higher education entrance qualification as well as preparatory courses are relevant for the prior physical-technical competencies of engineering studies.

(C) 2015 Behrendt et al.; licensee Springer. This is an open access article distributed under the terms of the Creative Commons Attribution License (http://creativecommons.org/licenses/by/4.0), which permits unrestricted use, distribution, and reproduction in any medium, provided the original work is properly credited. 
Against this background, this article addresses the question of which physicaltechnical prior competencies students in Germany start their engineering studies with. Furthermore, it analyzes the influence of e.g. formal qualifications, curricular weights ${ }^{\mathrm{a}}$ in school, or participation in preparatory courses on these prior competencies.

\section{State of research}

Structure of competencies and proficiency scaling

Results from large scale assessments below academic level suggest that multidimensional models are most suitable for representing the structure of competencies in the beginning of studies and document relatively high correlations between the subcategories of competency at the same time (e.g. Klieme et al. 2001). However, studies in the industrial-technical field below academic level show that in the beginning of apprenticeship, uni-dimensional models of technical competencies are better fitting to the data than multi-dimensional ones (Geißel 2008; Gschwendtner 2008). It seems therefore uncertain whether a multi- or a uni-dimensional model of the physical-technical prior competencies is more adequate. In the case that sub-dimensions are separable, we expect the differentiation to occur along content domains or along basics of the specific field (an overview in Nickolaus and Seeber 2013). Mechanics, which were primarily used for the design of the test for measuring physical-technical prior competencies, have two main curricular foci within the school curricula: statics and dynamics. These two potential sub-dimensions are characterized both by differing conceptual ideas and by differing cognitive requirements. Compared to statics, in the context of dynamics we also consider changes that occur over time; hence, situations are more complex and mathematical models which are needed for solving dynamic problems are more complex, too. The classification in statics and dynamics is also preferred in relevant educational books on Engineering Mechanics (e.g. Gross et al. 2012).

Proficiency scaling in technical fields below the academic level results in the following features which are predictive for the development of competencies: cognitive requirement (e.g. subsequent to Bloom 1956), complexity, independent modelling requirement, item formats, curricular foci respectively referencing qualities of data books allowed in the solving process (Geißel 2008; Gschwendtner 2008; Nickolaus et al. 2012). Mathematical requirements are partially explanatory as well (Seeber 2008).

\section{Predictors of study success}

The grades of the General Qualification for University Entrance (Abitur-grades) are the best predictors for study success (Schuler and Hell 2008). Their predictive power can, however, be increased by subject-specific tests at the beginning of the study phase. Against this background, subject-specific tests are additionally used in the international context for estimating future study success. To some extent (e.g. in Sweden and Japan (Thunsdorf and Schmitt 2013)), tests for the general aptitude for higher educational studies are conducted too. Admission procedures to higher education partly consult grades on special subjects or previous professional experience, the latter having hardly any prognostic power for study success (Nickolaus and Abele 2009). The prognostic validity of special school grades varies depending on the field of study as well. Abitur-grades in mathematics as well as global Abitur-grades reach higher prognostic validities in fields of study as mathematics, science, and engineering sciences than in linguistics or cultural studies (Trapmann et al. 2007). 
Numerous surveys from various fields of education indicate the great importance of subject-specific prior knowledge for the development of competencies (e.g. Stern 2001). In studies, which analyzed the relation between general intelligence, (subject-) specific prior knowledge, and training success, the high predictive power of the prior knowledge furthermore becomes obvious (Abele 2014; Schmidt-Atzert et al. 2004; Schuler and Höft 2006). In the non-academic field, surveys that analyze the impact of prior cognitive abilities, motivational features, and quality features of vocational education on the development of professional competencies reveal the great importance of the subject-specific prior knowledge (Abele 2014; Nickolaus et al. 2010, 2012). The relevance of the prior cognitive abilities and especially of the subject-specific prior knowledge is hereby decidedly illustrated.

On the contrary, the findings on the attained levels of prior knowledge are rather scarce. Subject-specific entry tests are used to some extent by several institutions of tertiary education, but IRT-based modelling is not being conducted, as far as we know. Consistent data across types of institutions of higher education is also missing. Largescale assessments below academic level give a good overview of the attained competency levels of the whole population. In the field of tertiary education however, it is an open question to what extent self-selection and external selection lead to systematical differences between the students of the different courses of studies. Effects of selfselection seem overall plausible, effects of external selection seem especially plausible in the case of performance-oriented admission procedures, some of them considering subject-specific grades as well.

The effects of the numerous propaedeutic offers, which are meanwhile available at a broad level in the beginning phase of study, are not known.

Subsequent to existing studies, we assume that the type of higher education entrance qualification becomes relevant for the attained levels of the prior competencies. Furthermore, the survey TOSCA indicates that graduates of technical gymnasia in Baden-Württemberg achieve similar performance levels in mathematics and physics as graduates of general gymnasia in other federal states in Germany (Neumann et al. 2009).

It is an open question whether gender effects will be observed. On the one hand, largescale assessments below the academic level document performance advantages for male respondents in mathematics and physics. On the other hand, it seems obvious that such differences are compensated by self-selection and external selection before entering the study phase. The performance levels documented within the existing studies justify the expectation of great gender-specific differences despite self-selection and external selection processes (Baumert et al. 2001). Regarding this, it shall be verified empirically whether the students entering engineering studies reach the levels fixed in the curricula of the general school system. The assumption that significant proportions of students do not reach them is very probable, as substantial efforts are currently being made in order to assure that the freshmen have the ability to keep up to tertiary education through subject-specific or more general propaedeutic preparatory courses.

\section{Methods}

The results presented in this article originate from a wide-ranging study on the modelling and measurement of competencies and their development within engineering studies. This survey aims at generating competency models for the main basic subjects on 
the one hand and explanatory models on the other hand. The overall project is laid out in a longitudinal section and involves machine engineering and construction engineering studies within two types of institutions of higher education: universities and universities of applied sciences. The contribution at hand shows results of the competency test in the area of technical-physical prior knowledge at the beginning of engineering studies, which was carried out in the winter semester 2012/2013.

The sample consists of 2345 students (1996 universities, 233 universities of applied sciences) from ten locations in Germany (6 universities and 4 universities of applied sciences). The access to the field was extremely difficult: We contacted many universities and universities of applied sciences asking for permission to carry out our survey with their students, getting many refusals. At some of the participating locations we managed to collect data from the total population, at other locations we encountered significant losses because students refused to participate. For this reason, we do not claim representativeness. Thus, the following results should be seen as first approach in this field. Further studies with representative samples should prove whether these results can be validated.

The test in the area of physical- technical prior knowledge at the beginning of engineering studies was designed according to the curricula of the junior high school and senior high school of general schools, focusing especially on contents which are relevant for the subject Engineering Mechanics within machine engineering and construction engineering studies (Hindenach 2012). Experts in the field of Engineering Mechanics were consulted about the test - they consider the test items require knowledge which should be built up in school and therefore, if present, supports students in successfully mastering their engineering studies.

In addition to this content-related testing, the following data, which was assumed to be relevant for the level of prior physical-technical competencies, was collected: educational biography (attended type of school, number of physics lessons), performance in school, participation in propaedeutic offers at the beginning of studies, general cognitive abilities, and mathematical competencies, motivation for mathematics and physics in school. The IQ was measured using the CFT scale 3 form A part 1 (Weiß and Cattell 1971, see also Cattell 1961). The test for measuring mathematical competencies was developed and piloted within the framework of this research project in cooperation with the department of mathematics education of the IPN Kiel ${ }^{\mathrm{c}}$ - for information on this test see Hauck (2012) and Neumann et al. (2014). The motivation for mathematics and physics in school was collected using an instrument from Prenzel et al. (1996), which was adapted for this context ${ }^{\mathrm{d}}$.

The following hypotheses are to be tested subsequent to the state of research outlined above:

H1: Students with general university entrance qualification and many physics lessons in school outclass students with a restricted entrance qualification (university of applied science entrance qualification, subject-specific entrance qualification) and fewer physics lessons in matters of physical-technical prior knowledge.

H2: Participants in the preparatory courses in the run-up to the beginning of studies are more high-capacity than non-participants.

H3: Gender-specific differences in the physical-technical prior knowledge cannot be observed. 
H4: No significant differences in the physical-technical prior knowledge of construction engineering students and machine engineering students are found.

H5: However, differences between students in universities and students in universities of applied sciences are expected.

H6: General cognitive abilities and mathematical competencies are predictive for the physical-technical prior knowledge.

H7: The difficulty features from other technical and scientific domains are explanatory for the proficiency scaling of the physical-technical prior knowledge.

Additionally, the following question is to be answered:

Q1: Is a multi-dimensional or a uni-dimensional structure more adequate for the modelling of the physical-technical prior knowledge of engineering students?

\section{Results and discussion}

Results on the structure of competencies and the proficiency scaling of the physicaltechnical prior competency are first presented. Afterwards, explanatory factors for the attained levels of the physical-technical competency are shown.

\section{Modelling of the technical-physical prior competencies}

Structure of competencies

Items for the two content dimensions statics and dynamics (see above) were developed in a first step. Following the wish of experts in the field of Engineering Mechanics, further items were developed, requiring the application of fundamental principles of Engineering Mechanics. In our view, this group of items is theoretically describable through conceptual knowledge (Rittle-Johnson and Siegler 1998). Differentiations according to criteria of cognitive psychology (types of knowledge) hardly exist in the nonacademic field: Until now, only Pittich (2013) claims to have separated conceptual knowledge from other types of knowledge ${ }^{\mathrm{e}}$.

Fundamental principles have cross-situational importance and are often taught only implicitly in institutional contexts. In schools, especially in scientific and technical fields, teachers often mainly focus on specific procedures respectively specific approaches for solving types of problems. Fundamental principles are developed in various contexts and, in some cases, are based on everyday experience ${ }^{f}$. Barriers may arise when fundamental principles have to be applied; in familiar contexts, however, their application may happen routinely. As a consequence, conceptual knowledge is related to problem solving according to Dörner (1976) respectively to schema creation according to Bendorf 2002(, see also Rumelhart and Norman 1981). For collecting conceptual knowledge, we introduce the dimension "basic ideas" with the following working definition:

For us, basic ideas on Engineering Mechanics represent general ideas about interdependencies of Engineering Mechanics systems. These ideas are based on knowledge from different contexts and individual experience and have to be applied to the particular tasks in Engineering Mechanics.

Subsequent to the considerations outlined above, three competency structure models were compared, using Rasch-models (1 PL): 
- A one-dimensional model

- A two-dimensional model with the subcategories "curricular" and "basic ideas". "Curricular" covers valid subjects across schools and "basic ideas" covers basic mechanical concepts that do not necessarily have to be dealt with in all school types and locations ${ }^{\mathrm{g}}$.

- A three-dimensional model, where the subcategory "curricular" was further divided into the subcategories "statics" and "dynamics".

The model comparison (Figure 1) accounts for the three-dimensional model as fitting best to the data ${ }^{\mathrm{h}}$ - question Q1 is answered with this. Relatively high latent correlations between statics and dynamics as well as between dynamics and basic ideas were found. The correlation between statics and basic ideas turns out to be considerably lower. The reliability is only partly satisfying, probably because of the small number of items within each subcategory (Table 1).

The correlation between statics and dynamics seems plausible. However, the strong correlation differences between the three dimensions remain unclear. We can exclude that the low correlation between statics and basic ideas is a consequence of test construction, i.e. of curricular focus within the "basic ideas", because static problems are also explicitly addressed within the "basic ideas" dimension.

The great heterogeneity in the entry competencies seems impressive altogether and is documented for both courses of studies. The distribution of the respondents within the subcategories (see Figure 2) documents a relatively strong occupation in the lower part for the subcategories statics and basic ideas. Whether these unfavorable starting conditions make successful studies possible should be verified empirically; it seems, however, questionable according to the state of research presented above.

\section{Proficiency scaling}

The proficiency scaling was conducted subsequent to Hartig (2007) for a unidimensional model; it was not possible to implement proficiency scaling for a multidimensional model because of the relatively small number of items.

The following difficulty parameters were found:

- Requirement level (reproduction, establishing of connections, generalization, and reflection).

- Type of knowledge (declarative, procedural).

- Sketch (yes, no): This feature includes both sketches contained in the item formulations, which have to be read, interpreted, and/or understood for correctly solving the items or sketches as part of the respondents' answers.

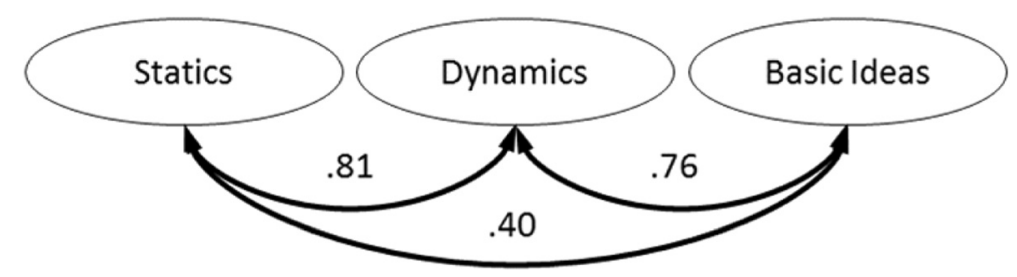

Figure 1 EMe_e (Engineering Mechanics entry test): structure of competencies. 
Table 1 EMe_e: reliability

\begin{tabular}{llllllll}
\hline Reliability & 3-dim. & & & & 2-dim. & 1-dim. \\
\cline { 2 - 3 } & Statics & Dynamics & Basic ideas & & Curricular & Basic ideas & \\
\hline EAP/PV-Rel. & .58 & .65 & .55 & .64 & .55 & .66 \\
WLE-Rel. & & & & & & & .58 \\
Number of items & 5 & 9 & 6 & 14 & 6 & 20 \\
\hline
\end{tabular}

- Units (yes, no): It is categorized here whether the solution requires working with measurement units.

- Mathematics (yes, no): This feature indicates whether mathematical methods or concepts are needed for the solution.

The rating of the items was performed by two experts separately. In the case of disagreement, the experts discussed in order to reach agreement. The relevance of the difficulty features was determined by means of a forward multivariate regression analysis. The variance explained through the features mentioned above reaches $56 \%$. Table 2 presents the results of regression in detail.

The following other features were considered as well, but proved not to be relevant for item difficulty: number of solution steps, calculating with numbers or variables, occurrence or creating of charts, and reference quality of data books.

Hypothesis 7 is supported only partially. We replicated the predictive power of the following features for item difficulty: cognitive requirement levels, relevance of mathematical requirements, and item formats (sketches). The number of solution steps

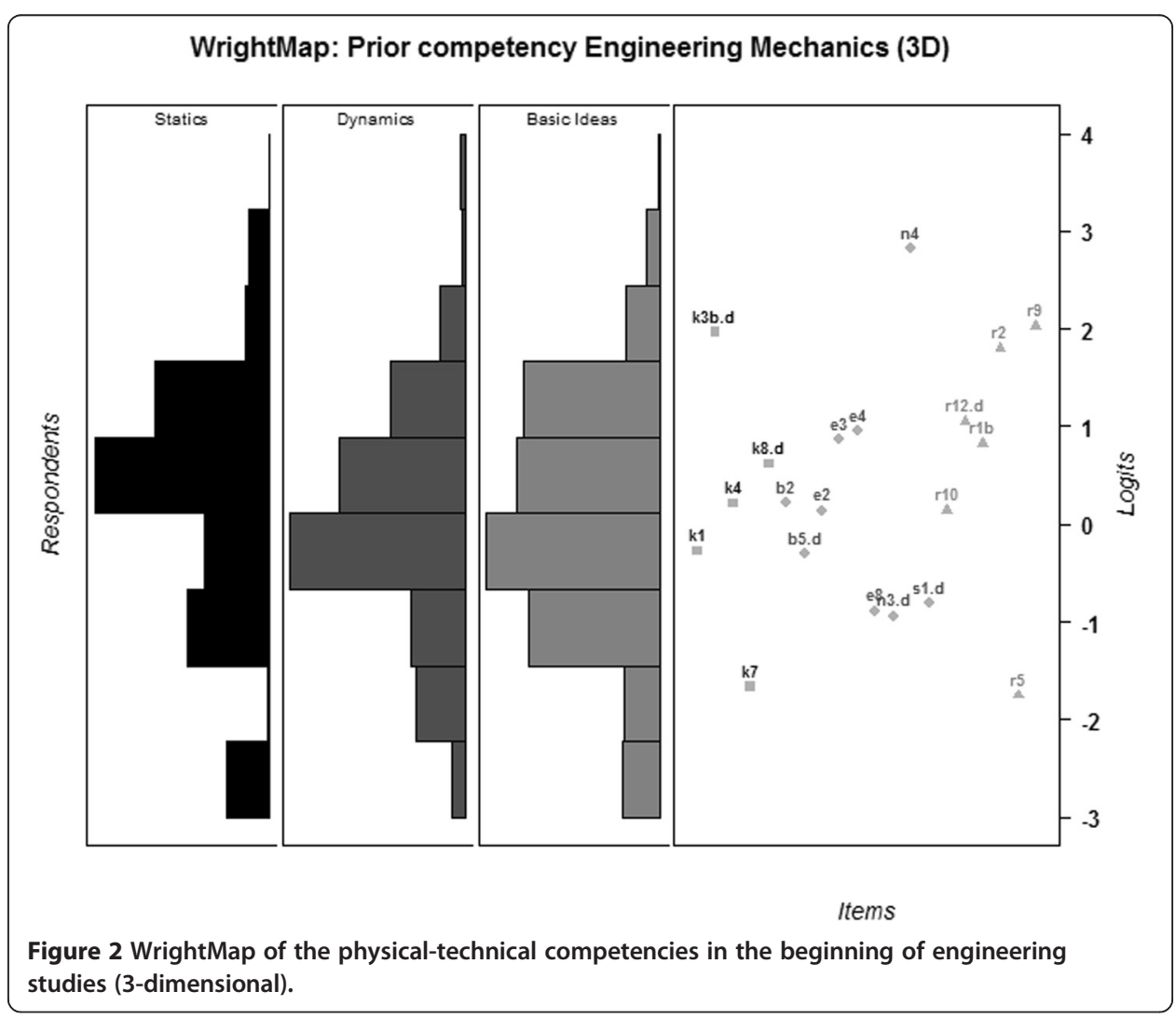


Table 2 Multi-variate regression analysis for the explanation of item difficulty

\begin{tabular}{llll}
\hline Variable & Category & $\boldsymbol{\beta}$ & $\mathbf{p}$ \\
\hline Requirement level & Reproduction & Ref & \\
& Establishing of connections & .44 & .05 \\
& Generalization and reflection & .56 & $<.05$ \\
Type of knowledge & Declarative & Ref & .05 \\
Sketch & Procedural & .40 & \\
& No & Ref & .07 \\
Units & Yes & .34 & \\
& No & Ref & .09 \\
Mathematics & Yes & -.31 & \\
& No & Ref & .21 \\
Model & Yes & .27 & $<.01$ \\
\hline
\end{tabular}

proves to be non-predictive. The type of knowledge proves to be explanatory as well, in contrast to the results documented in other technical fields (Nickolaus et al. 2011).

The competency level model (Figure 3), which was generated on this basis, is the result of the procedure used in Hartig (2007). Although a higher number of items would have been preferable for this purpose, the generation of the competency levels facilitates the communication about the competencies achieved by the students and should be seen as first approach in this field. Further studies with an extended item pool are necessary for shoving whether these findings can be replicated.

The competency level model contains three levels that can be described qualitatively. For the sake of completeness of the proficiency scaling procedure (Hartig 2007), we list here two further levels. It is useful to merge these two levels for interpretation purposes; further studies have to show whether these two levels are actually separable. The detailed description of the competency levels is presented in the following.

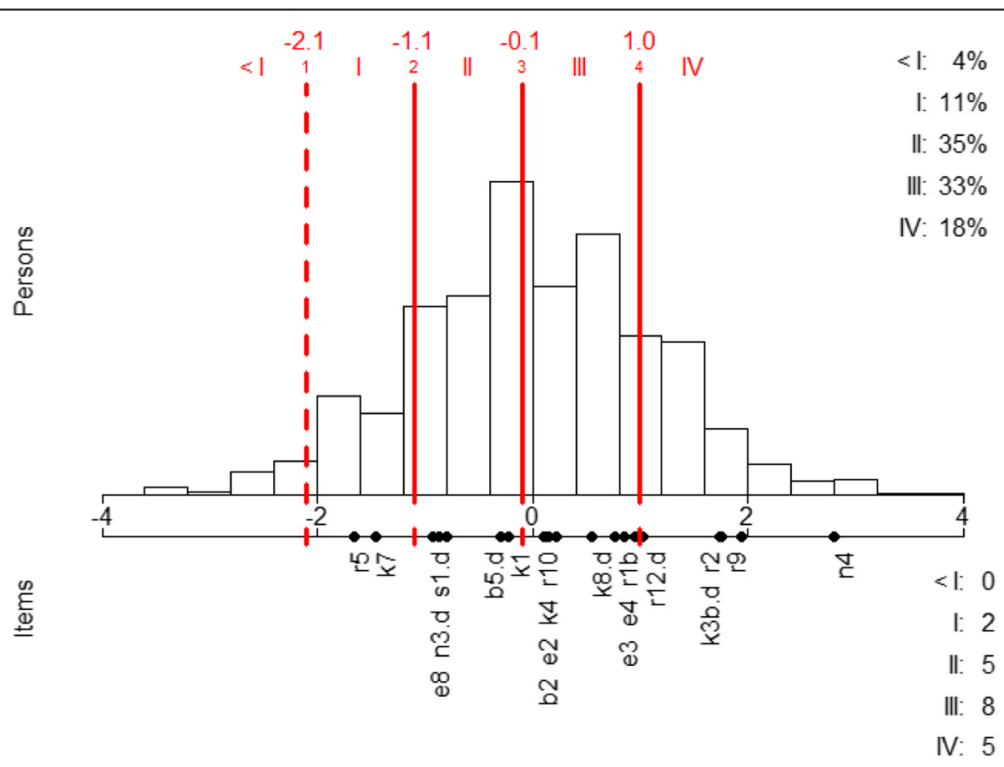

Figure 3 EMe_e: competency level model (according to Hartig 2007). 
Respondents on levels $<$ I and I are not able solve the simplest mechanical items. A detailed description of the abilities on these levels is not possible because of the shortage of items.

Respondents on level II have the ability to name the basic mechanical terms and to correctly solve items containing mechanical problems with simple connections (see e.g. the item in Figure 4). Coping with the requirement only calls for: knowledge about the concept of force and the ability to determine the resultant of two forces, and taking into consideration their value, direction, and measurement unit. We assume this type of item as relatively familiar. It is striking that approximately $15 \%$ of the respondents do not answer correctly to such simple items although we assume that choosing engineering studies implies at least positive self-concepts in this segment because of the generally known difficulty attributions.

Respondents on level III have the ability to name the common mechanical terms and to correctly solve mechanical problems containing many connections. They thereby master fundamental mechanical procedures and the required (simple) mathematical methods. Figure 5 shows an exemplary item, where the required tractive force for a tackle system shall be computed - for solving the item, it is necessary to understand the distribution of forces on the two rolls. The mathematical requirements are trivial, similar to those on level II. 33\% of the respondents are situated on this competency level. This type of item should at least be partially solved by students from Hauptschule ${ }^{k}$ and Realschule, according to curricular fixations.

Not before level IV, respondents have the ability to mathematically model more complex mechanical problems. Students on this level name complex mechanical terms. They are able to solve mechanical problems with many connections which require the understanding of overarching mechanical concepts. They master complex mechanical procedures and are capable of using simple mathematical methods (vector algebra and trigonometry) for this purpose. Figure 6 shows an example which requires the computation of the horizontal and vertical force components. This item implies trigonometric knowledge that should already be available in junior high. $18 \%$ of the students reach this level.

From a practical perspective, this means that teachers in higher education cannot expect a relatively large part of their students to master the basic technical-physical contents from general school. Hence this knowledge has to be developed or updated. A

Compute the resulting force $F_{\text {res }}$ of the forces $F_{1}$ and $F_{2}$ in the case presented below! Fill in the solution in the area provided!
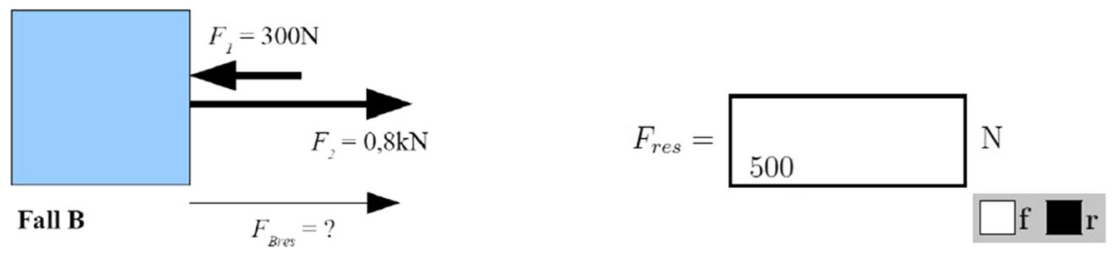

(Drawing not to scale)

Figure 4 Exemplary item on level II with solution: k7; statics; N=1475; LQ=.769; $\delta=-1.659(0.071)$; wMNSQ $=0.94$. 
The illustration below shows a tackle system which is loaded with a body with weight $F_{G}=100 \mathrm{~N}$

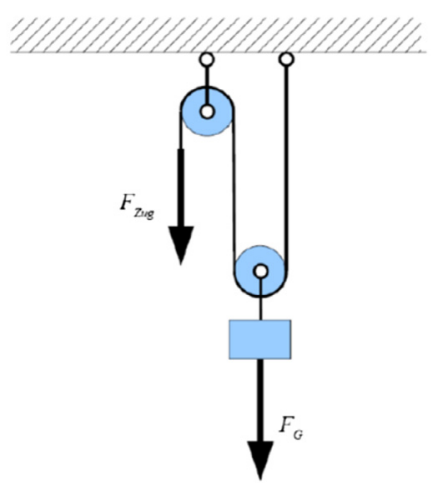

(Drawing not to scale)

Which tensile force $F_{Z u q}$ is at least necessary in order to hold the body in its position? Fill in the solution in the area provided!

$$
F_{Z u g}=5 \mathrm{~N}
$$

Figure 5 Exemplary item on level III with solution: $k 1$; statics; $N=1485 ; \mathrm{LQ}=.533 ; \delta=-0.275(0.060)$; wMNSQ $=1.05$.

solid physical-technical prior knowledge may not even be attested for students on level II. Altogether, approximately $80 \%$ of the students do not have a solid physical-technical prior knowledge.

The following section clarifies whether the two types of institutions of higher education are affected by this phenomenon to the same extent and whether there are specific

The illustration below shows a body on a rough surface absorbing the force $F_{A}=26 \mathrm{kN}$ at an angle $\alpha=36^{\circ}$ without sliding.

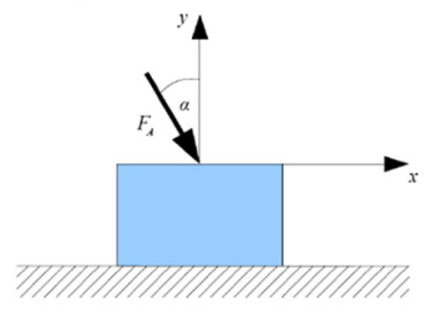

(Drawing not to scale)

Compute the components of the force vector $\overrightarrow{F_{A}}$ in the direction of $x\left(F_{A x}\right)$ and in the direction of $y\left(F_{A y}\right)$ !

Fill in each solution in the area provided!

a) Component of the force vector $\overrightarrow{F_{A}}$ in the direction of $x$ :

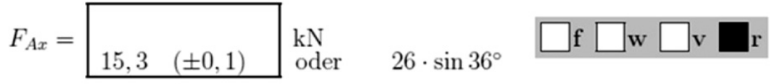

b) Component of the force vector $\overrightarrow{F_{A}}$ in the direction of $y$ :

$$
F_{\text {Ay }}=\begin{array}{|ll}
\hline 21,0 \quad( \pm 0,1) & \mathrm{kN} \\
\text { oder } & 26 \cdot \cos 36^{\circ}
\end{array} \square \mathrm{f} \square \mathrm{w} \square \mathrm{v} \square \mathrm{r}
$$

Figure 6 Exemplary item on level IV with solution: $a)+b)$ : $k 8 ;$ statics; $N=1989 ; L Q=.381 ; \delta=0.616$ (0.054); wMNSQ=0.98. 
groups that are particularly affected by it. For this purpose, we will verify hypothesis $1-$ 6 and simultaneously examine other connections.

Prior competencies' dependency on education biographies, gender, general cognitive and mathematical abilities, participation in propaedeutic courses, and domain-specific motivation

For examining the above hypotheses, we shall run t-tests and analyses of variance (comparisons of mean values). Tables 3 and 4 give an overview of the resultant significances of the t-tests and of the analyses of variance. Furthermore, we computed Cohen's $d$ as effect size for dichotomous variables and the partial eta-squared $\left(\eta^{2}\right)$ in the case of the ANOVAS. Selection effects of the sample are possible here, but were not taken into consideration so far.

We found relatively strong differences in the physical-technical competencies depending on the course of studies, the participation in preparatory courses in physics, and the gender: mechanical engineering students, male respondents, and students having participated in preparatory courses in physics achieve much better results. This means that hypotheses $\mathrm{H} 3$ and $\mathrm{H} 4$ are falsified. $\mathrm{H} 2$ is, however, supported, whereby the preparatory course in physics is especially relevant. It seems interesting here that the preparatory course in physics is frequented more seldom than the preparatory course in mathematics.

We identified considerably lower, but still significant effects of the type of institution of higher education, mathematical competencies, number of physics lessons in school, and type of higher education entrance qualification. Hence, the hypotheses $\mathrm{H} 1, \mathrm{H} 5$, and H6 are supported. However, the effect sizes are rather small. It seems that the differences between the courses of study are significantly higher than between the types of higher education entrance qualifications (Figures 7 and 8). Differences due to the type of higher education entrance qualification exist only between the general entrance qualification on the one hand and the university of applied sciences entrance qualification and the subject-specific entrance qualification on the other hand. Students with the last two types of higher education entrance qualifications do not show significant differences in the physical-technical prior competencies.

For a more detailed representation of the effect sizes presented in Tables 3 and 4 we depicted selected connections using box-plots (with means and standard deviations).

Table 3 The physical-technical entry competencies' dependency on type of institution of higher education, course of studies, gender, participation in preparatory courses

\begin{tabular}{|c|c|c|}
\hline Variable & Level & Cohens d \\
\hline Type of institution of higher education $(\mathrm{N}=2306)$ & $\begin{array}{l}\text { University of applied sciences }(9,5 \%) \\
\text { University }(90,5 \%)\end{array}$ & $0.169^{* *}$ \\
\hline Course of studies $(N=2181)$ & $\begin{array}{l}\text { Construction engineering }(8,5 \%) \\
\text { Mechanical engineering }(91,5 \%)\end{array}$ & $0.541^{* * *}$ \\
\hline Gender $(N=298)$ & Male $(87,5 \%)$ | female $(12,5 \%)$ & $-0.378^{*}$ \\
\hline Preparatory course in mathematics ( $N=293)$ & No (49\%) | yes (51\%) & -0.161 \\
\hline Preparatory course in physics $(N=293)$ & No (89\%) | yes (11\%) & $0.410^{*}$ \\
\hline Other preparatory course $(\mathrm{N}=293)$ & No $(95 \%)$ | yes (5\%) & 0.113 \\
\hline
\end{tabular}

The last column specifies Cohen's $d$ and the significance of the t-Test. Levels of significance: ${ }^{* * *} \mathrm{p}<.001 ;{ }^{* *} \mathrm{p}<.01 ;{ }^{*} \mathrm{p}<.05$. 
Table 4 The physical-technical entry competencies' dependency on education biographies, general cognitive abilities, performance data from school, motivation

\begin{tabular}{|c|c|c|}
\hline Variable & Level & $\eta^{2}$ \\
\hline Year of birth $(N=296)$ & & $0.024^{* *}$ \\
\hline \multirow{4}{*}{$\begin{array}{l}\text { Type of higher education entrance } \\
\text { qualification }(\mathrm{N}=)\end{array}$} & General entrance qualification $(68,5 \%)$ & \multirow[t]{4}{*}{$0.027^{*}$} \\
\hline & $\begin{array}{l}\text { University of applied sciences } \\
\text { entrance qualification (10\%) }\end{array}$ & \\
\hline & Subject-specific entrance qualification (21\%) & \\
\hline & Special regulation $(0,5 \%)$ & \\
\hline $\begin{array}{l}\text { Year of higher education entrance } \\
\text { qualification }(N=295)\end{array}$ & & 0.004 \\
\hline \multirow{3}{*}{$\begin{array}{l}\text { Final grade of the higher education } \\
\text { entrance qualification }(N=293)\end{array}$} & $1.0-1.5(9 \%)$ | 1.6-2.2 (45,5\%) & \multirow[t]{3}{*}{$0.123^{* * *}$} \\
\hline & $2.3-2.9(34,5 \%) \mid 3.0-3.6(11 \%)$ & \\
\hline & $>3.6(0 \%)$ & \\
\hline \multirow{2}{*}{$\begin{array}{l}\text { Number of mathematics lessons } \\
\text { per week (senior high school) }(N=292)\end{array}$} & $0(1,5 \%) \mid 1-2(3,5 \%)$ & \multirow[t]{2}{*}{0.001} \\
\hline & $3-4(67,5 \%) \mid>4(27,5 \%)$ & \\
\hline \multirow{2}{*}{$\begin{array}{l}\text { Type of final examination in } \\
\text { mathematics }(N=291)\end{array}$} & Both (6\%) | none (4\%) & \multirow[t]{2}{*}{$0.039^{* *}$} \\
\hline & Oral $(1,5 \%) \mid$ written $(88,5 \%)$ & \\
\hline \multirow{2}{*}{$\begin{array}{l}\text { Grade of final examination in } \\
\text { mathematics }(N=287)\end{array}$} & $1.0-1.5(29,5 \%) \mid 1.6-2.2(30,5 \%)$ & \multirow[t]{2}{*}{$0.117^{* * *}$} \\
\hline & $2.3-2.9(16,5 \%)|3.0-3.6(17,5 \%)|>3.6(6 \%)$ & \\
\hline \multirow{2}{*}{$\begin{array}{l}\text { Number of physics lessons per week } \\
\text { (senior high school) }(\mathrm{N}=294)\end{array}$} & $0(17 \%) \mid 1-2(19 \%)$ & \multirow[t]{2}{*}{$0.104^{* * *}$} \\
\hline & $3-4(42 \%) \mid>4(22 \%)$ & \\
\hline \multirow{2}{*}{$\begin{array}{l}\text { Type of final examination } \\
\text { in physics }(N=291)\end{array}$} & Both (3,5\%) | none (55\%) & \multirow[t]{2}{*}{$0.046^{* *}$} \\
\hline & Oral $(1,5 \%) \mid$ written (40\%) & \\
\hline \multirow{2}{*}{$\begin{array}{l}\text { Grade of final examination } \\
\text { in physics }(N=231)\end{array}$} & $1.0-1.5(24,5 \%) \mid 1.6-2.2(32,5 \%)$ & \multirow[t]{2}{*}{$0.092^{* * *}$} \\
\hline & $2.3-2.9(24 \%)|3.0-3.6(14 \%)|>3.6(5 \%)$ & \\
\hline \multirow{2}{*}{$\begin{array}{l}\text { Federal state of higher education } \\
\text { entrance qualification }(N=289)\end{array}$} & bw (78\%)| by (4\%) | hs (1\%) | nrw (15\%) & \multirow[t]{2}{*}{0.021} \\
\hline & ns (1\%) | rp (1\%) & \\
\hline \multirow{3}{*}{$\begin{array}{l}\text { Type of school of higher education } \\
\text { entrance qualification }(N=291)\end{array}$} & AG (54,5\%) | ber.G (2\%) | FS (2,5\%) & \multirow[t]{3}{*}{$0.096^{* * *}$} \\
\hline & int.GS (2\%) | OS/KO (27\%) | TG (9\%) & \\
\hline & other $(3 \%)^{\mathrm{m}}$ & \\
\hline \multicolumn{2}{|l|}{$\begin{array}{l}\text { Intrinsic/identified motivation } \\
\text { mathematics }(\mathrm{N}=283)\end{array}$} & $0.014^{*}$ \\
\hline \multicolumn{2}{|l|}{$\begin{array}{l}\text { Intrinsic/identified motivation } \\
\text { physics }(N=247)\end{array}$} & $0.047^{* * *}$ \\
\hline \multicolumn{2}{|l|}{ Mathematical competency $(\mathrm{N}=315)$} & $0.207^{* * *}$ \\
\hline \multicolumn{2}{|l|}{ Intelligence $(N=531)$} & $0.074^{* * *}$ \\
\hline
\end{tabular}

The last column specifies the partial eta-squared $\eta^{2}$ and the significance of the ANOVA.

Levels of significance: ${ }^{* * *} \mathrm{p}<.001 ;{ }^{* *} \mathrm{p}<.01 ;{ }^{*} \mathrm{p}<.05$.

The width of each box represents the proportion of the respondents in the respective category referred to the total number of respondents. The whiskers represent the span.

We find significant differences in the composition of the sample, both in the case of the type of institution of higher education, and in the case of the course of studies (Figures 9 and 7). Hence, for computing the effect sizes, we take the numbers of respondents in the subgroups into consideration ${ }^{\mathrm{m}}$. Both effects are significant, as mentioned above. Hypothesis 4 is falsified, hypothesis H5 is confirmed. The effect regarding the course of studies is much more pronounced than the effect regarding the type of institution of higher education. The comparison of the respondents belonging to the two types 


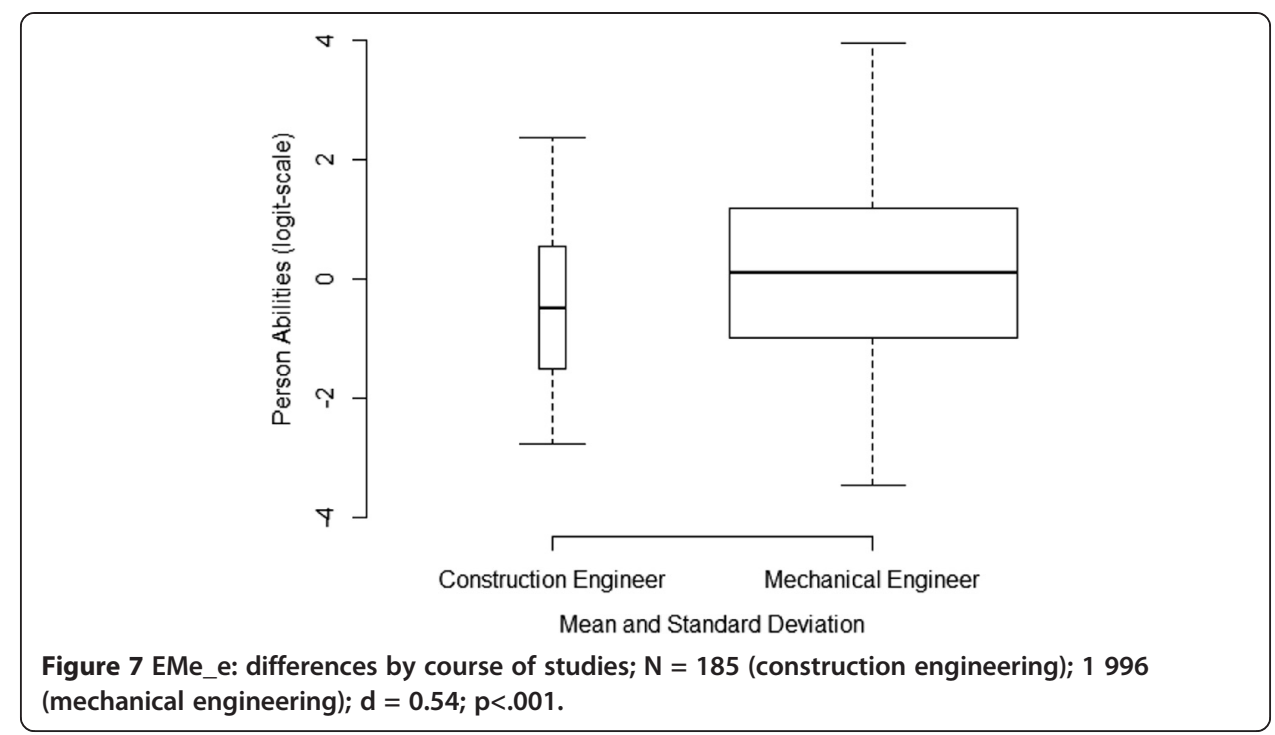

of institutions of higher education shows inequalities in the variances of the two groups $(\mathrm{F}(1)=4.21 ; \mathrm{p}<.05)$ : the variance at universities $(1.26)$ is higher than aniversities of applied sciences (0.98). This fact may be attributed to the different group sizes.

We find various numbers of respondents in the categories of type of higher education entrance qualification (Figure 8), however the differences are not as big as in the case of the type of institution of higher education or the course of studies. The approximate equality between the students with a subject-specific entrance qualification and a university of applied sciences entrance qualification $(\mathrm{d}=0.03$; n.s.) is evident, as well as the big performance difference of the students having achieved the general entrance qualification $(\mathrm{d}=-0.37 ; \mathrm{p}<.1$ compared to the students having achieved a subjectspecific entrance qualification, respectively $\mathrm{d}=-0.34 ; \mathrm{p}<.01$ compared to the students having achieved a university of applied sciences entrance qualification).

There are $12 \%$ women in the sample (Figure 10). This percentage is a little smaller than the average for Germany found in the beginning of engineering studies in the

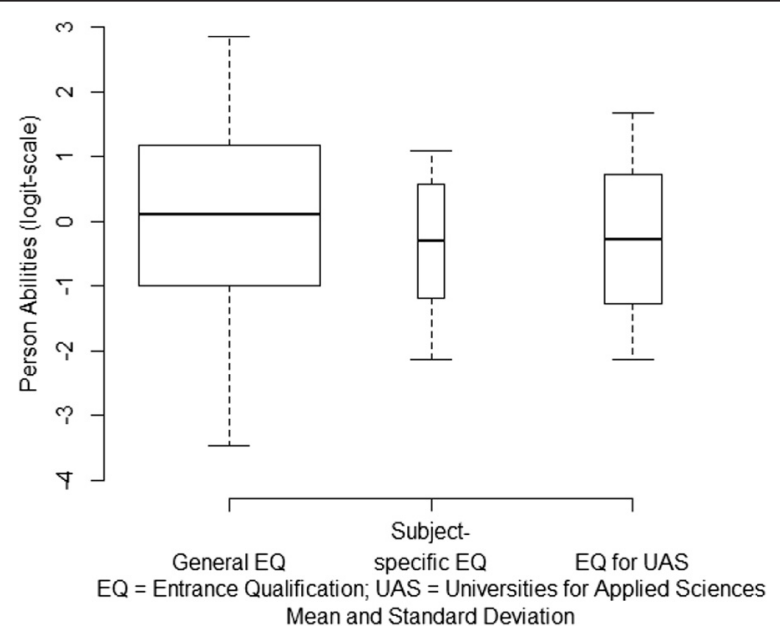

Figure 8 EMe_e: differences by type of higher education entrance qualification; $N=202$ (general EQ); 29 (subject-specific EQ); 63 (EQ for universities of applied sciences); $\eta^{2}=0.03 ; p<.05$. 


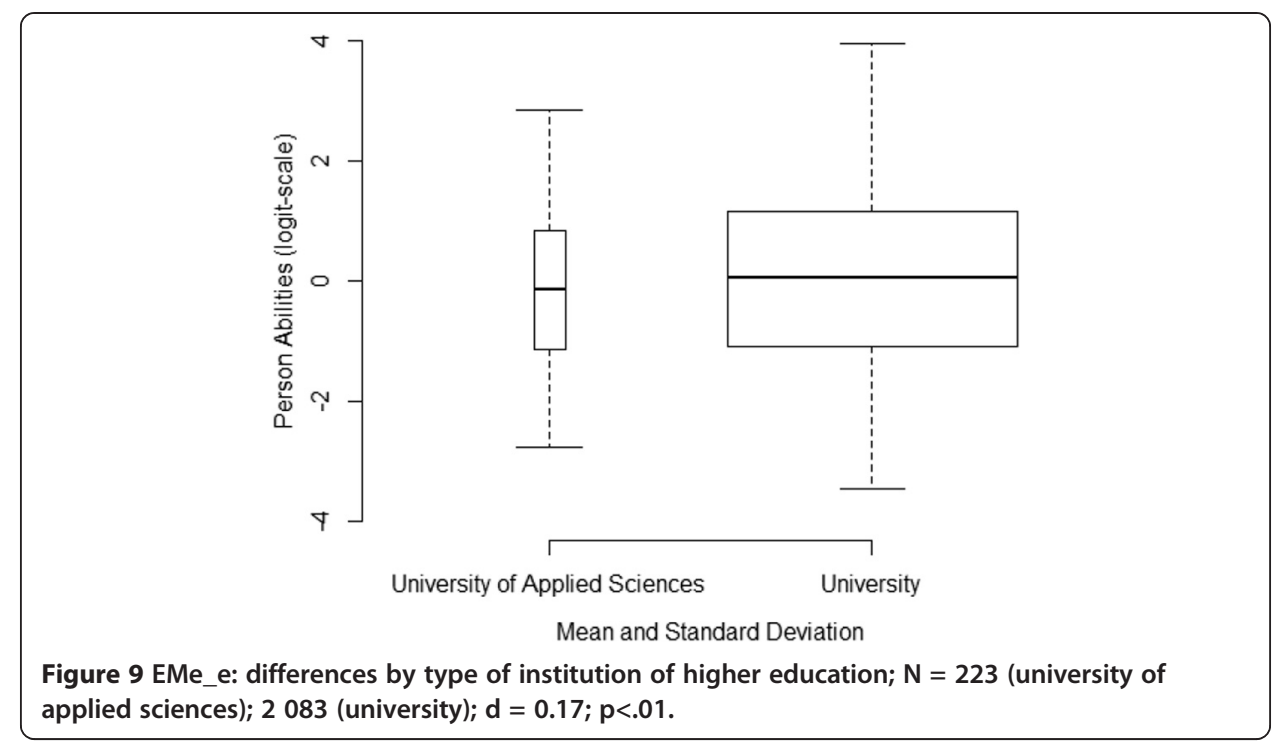

winter semester of 2013/14 (18,8\%) (Statistisches Bundesamt 2013). Female respondents have a significantly lower physical-technical prior competency than male respondents. This finding contradicts the assumption made by hypothesis H3. This means that the self-selection for engineering studies, which we had assumed, does not lead to the expected equalization of performances between male and female students.

The differences in the physical-technical prior competencies between respondents having and not having participated in the preparatory courses are particularly interesting with regard to the orientation and design of the preparatory courses. The preparatory courses in physics are only little frequented $(11 \%)$, however they seem to produce a serious difference (Figure 11). In principle, this difference may be caused by the influence of selection, i.e. by a positive selection of the participants.

Contrary to the findings of Pant et al. (2013), which could not confirm any effects of the curricular weights on the performances, we find clear effects in our survey $\left(\eta^{2}=0.1\right)$.

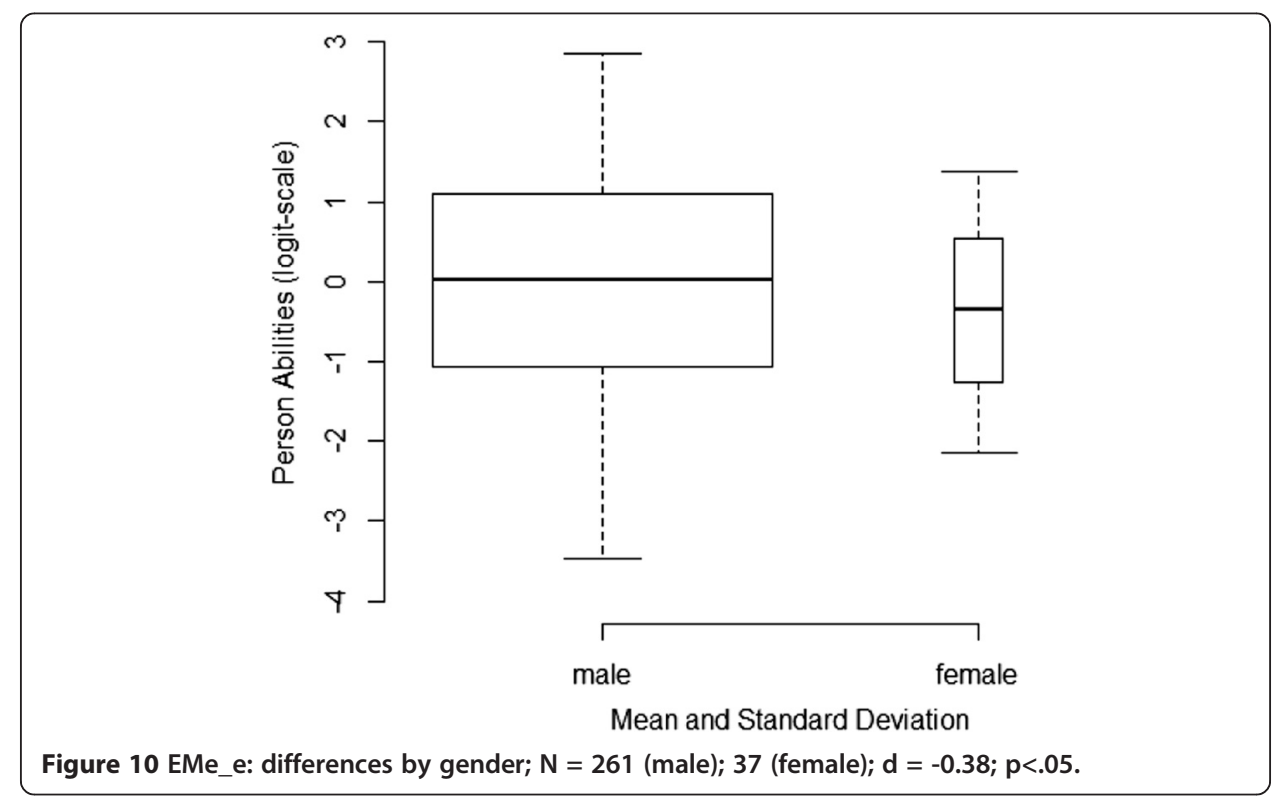




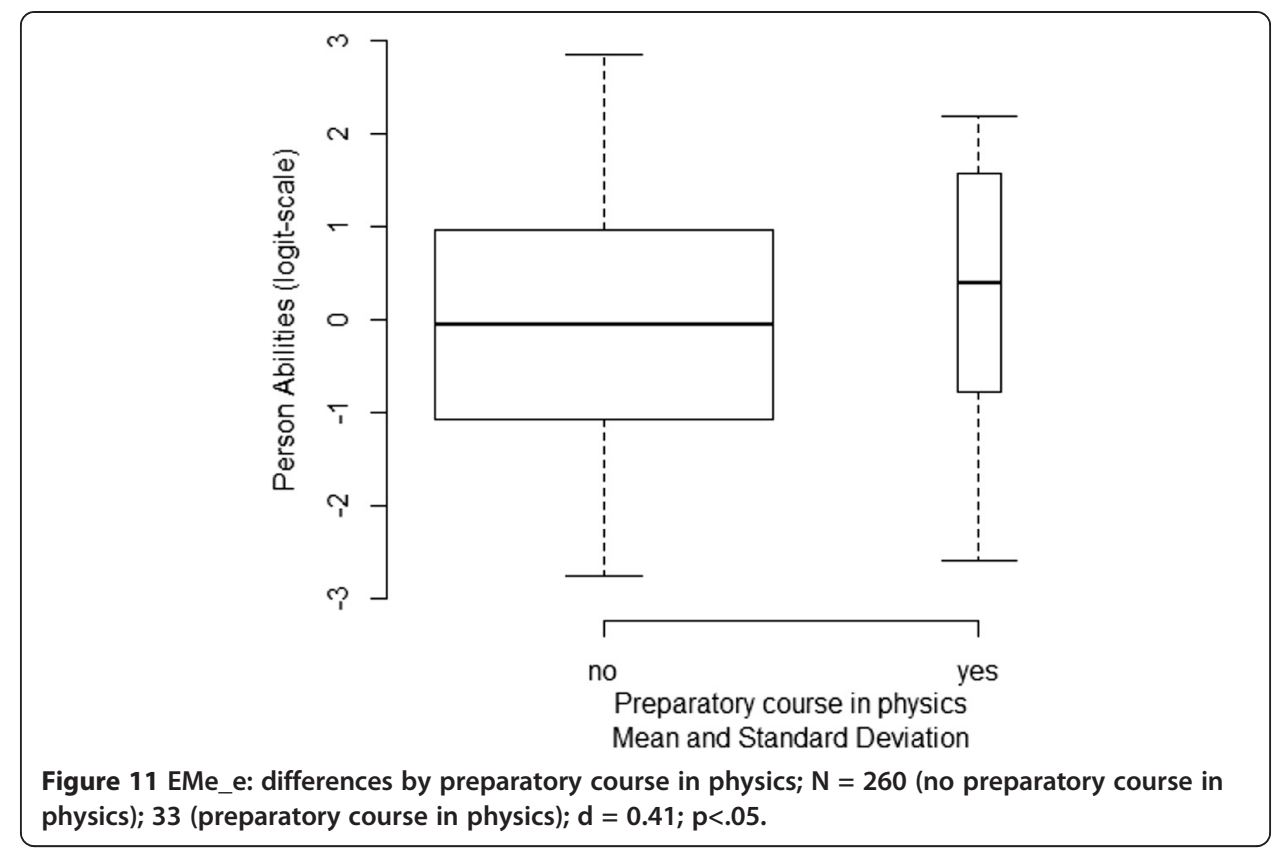

Especially freshmen who did not have any physics lessons in senior high school perform significantly worse, although mechanics was only taught in junior high for all students. Figure 12 illustrates the above mentioned.

\section{Conclusions}

The results of our survey reveal a big variance in the physical-technical prior competencies. Hence, we find a substantial proportion of freshmen with significant competency deficits. We assume that these competency deficits constitute a factor which makes (the beginning of) engineering studies more difficult.

The hypotheses, which indicate a difference in the physical-technical competencies caused by formal entrance requirements for tertiary education, were confirmed, where

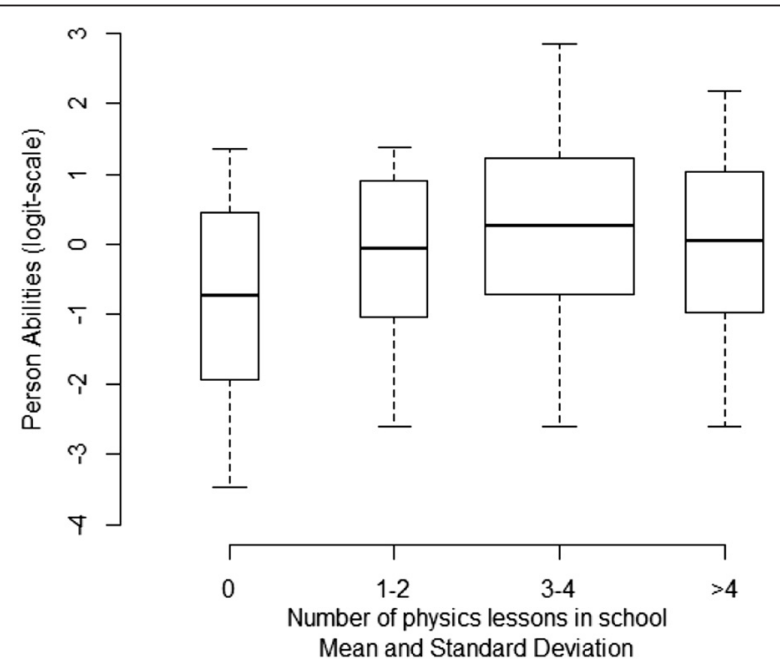

Figure 12 EMe_e: differences by number of physics lessons per week in senior high school; $\mathrm{N}=49$ (0 physics lessons in school); 56 (1-2 physics lessons in school); 124 (3-4 physics lessons in school); 65 ( $>4$ physics lessons in school); $\eta^{2}=0.10 ; p<.001$. 
the differences only exist between students with general entry qualification on the one hand and subject-specific entrance qualification and university of applied sciences entry qualification on the other hand. For respondents with university of applied sciences entrance qualification, which is usually acquired in "short forms", we assume lower curricular weights of the education in physics than for respondents with a general entrance qualification.

The differences in the physical-technical prior knowledge, depending on the number of physics lessons the students had in school proves to be remarkably high. The participation in the preparatory course in physics, which provides further learning opportunities, shows relatively strong advantages for the students having participated. We should point out here that the test for measuring the physical-technical prior knowledge addresses primarily subjects which are situated in the junior high period of regular school and hence there is a long period of time between the acquisition of the knowledge and the moment of testing.

The performance differs between the two types of institution of higher education, whereat students from universities have better physical-technical prior competencies than students from universities of applied sciences. Our finding is expectationconformal, because these different types of institutions of higher education have different entry requirements: especially for freshmen of universities of applied sciences we find a lesser percentage of general higher education entry qualifications and even technicians are allowed to start their engineering studies here (see also Jürgens and Zinn 2012, Zinn 2012).

The performance also differs between the two courses of study: we find advantages for mechanical engineering students compared to construction engineering students. This finding is expectation-conformal too, because mechanical engineering studies are very attractive in Germany: mechanical engineering is an especially innovative field, the labor market conditions for mechanical engineers are excellent and mechanical engineering has a good image, as it is the supporting pillar of the German export economy.

We find a multi-dimensional structure for the physical-technical competencies in the beginning of engineering studies as most suitable. The subcategories "statics" and "dynamics" are primarily distinguished along content domains. Furthermore, we find the subcategory "basic ideas", representing general ideas about interdependencies of Engineering Mechanics systems. These ideas are based on knowledge from different contexts and individual experience and have to be applied to the particular tasks in Engineering Mechanics. We further computed other models, which the theoretical bases are not yet well enough differentiated for. Mathematical requirements e.g. are generating structure here. We experience that the basic ideas are stable across all computed models. Further studies with an extended item pool have to show whether the found competency structure and the operationalization of the basic ideas will be replicated.

Considering matters of education policy, the curricular weights provide an option for heading to the desired levels of prior competencies. This applies to the number of physics lessons in school and to the participation in preparatory courses in physics, both showing considerable effects. As the different entrance qualifications are accompanied by differing curricula in school and, at the same time, the different entrance qualifications have relatively strong effects on the levels of the prior competencies, it needs to be ascertained which possibilities exist to create conditions in the respective 
contexts that are more conducive to the development of the required competencies. In the academic teaching, strengthening the preparatory courses in physics is a possible solution, as they seem less frequented than the preparatory courses in mathematics. Changes in the curricula of the physics lessons in the different school types should turn out to be more challenging, because of the confrontation with competing ideas concerning the subjects. It remains to be seen whether the need for action, which finds expression in the achieved competency levels presented above, is sufficient for taking appropriate actions.

\section{Endnotes}

${ }^{a}$ Curricular weights can be generated in two ways: on the one hand by the provision of relevant learning offers and on the other hand by the different content-related foci of the subject.

${ }^{\mathrm{b}}$ Complexity is determined e.g. by the number of relevant elements which have to be taken into consideration in the solving process as well as their linking or by the number of steps towards the solution (Nickolaus et al. 2012; see also Kauertz 2008).

chttp://www.ipn.uni-kiel.de/en/the-ipn/departments/mathematics-education.

${ }^{\mathrm{d}}$ Cronbach's alpha for the motivation for physics is 0,87 ; Cronbach's alpha for motivation for mathematics is 0,75 .

${ }^{\mathrm{e}}$ The attempt to empirically separate declarative and procedural knowledge using paper-pencil-tests does normally not succeed (Gschwendtner 2008, Geißel 2008).

${ }^{f}$ For example: How does the bending line of a bar look like?

${ }^{\mathrm{g}} \mathrm{An}$ expert rating confirmed our assumption according to which items belonging to the dimension "basic ideas" are only little represented in the school curriculum and it is necessary to apply fundamental principles of Engineering Mechanics for solving them.

$\mathrm{h}_{3}$ dim: AIC 36766, BIC 36915; 1 dim: AIC 37001, BIC 37122; $\chi^{2}(5)=246 ; \mathrm{p}<.001$.

3 dim: AIC 36766, BIC 36915; 2 dim: AIC 33877, BIC 37010; $\chi^{2}(3)=118 ; p<.001$.

${ }^{\mathrm{i}}$ Hauptschule is a type of secondary school in Germany, starting after elementary schooling, and offering Lower Secondary Education. Any student who went to a German elementary school can go to a Hauptschule afterwards, whereas students who want to attend a Realschule or Gymnasium need to have good marks in order to do so (Wikipedia).

${ }^{j}$ Realschule is a type of secondary school in Germany (Wikipedia).

${ }^{\mathrm{k}}$ Some authors call this effect size Hedges g (e.g. Bühner 2011, pp. 268).

${ }^{\mathrm{l}} \mathrm{bw}=$ Baden-Württemberg, by = Bayern, hs = Hessen, nrw = Nordrhein-Westfalen, $\mathrm{ns}=$ Niedersachsen, $\mathrm{rp}=$ Rheinland Pfalz.

${ }^{\mathrm{m}} \mathrm{AG}=$ general high school, ber.G = vocational high school, $\mathrm{FS}=$ vocational and technical school, int.GS $=$ integrated comprehensive school, $\mathrm{OS} / \mathrm{KO}=$ Oberschule/Kolleg (type of institution for adult education in Germany for attaining a higher education entrance qualification), TG = technical secondary school. 


\section{Author details}

${ }^{1}$ Institute of Education, Department of Vocational, Economic and Technical Education, University of Stuttgart, Geschwister-Scholl-Str. 24D, Stuttgart 70174, Germany. ${ }^{2}$ Institute of General Mechanics, RWTH Aachen University, Templergraben 64, Aachen 52062, Germany.

Received: 20 August 2014 Accepted: 15 January 2015

Published online: 15 February 2015

\section{References}

Abele, S (2014) Modellierung und Entwicklung beruffachlicher Kompetenz. Franz Steiner, Stuttgart

Baumert J, Klieme E, Neubrand O, Prenzel M, Schiefele U, Schneider W, Stanat P, Tillmann KJ, Weiß M (eds) (2001) PISA 2000. Basiskompetenzen von Schülerinnen und Schülern im internationalen Vergleich. Leske + Budrich, Opladen

Bausch I, Biehler R, Bruder R, Fischer PR, Hochmuth R, Koepf W, Schreiber S, Wassong T (2014) Mathematische Vor- und Brückenkurse. Konzepte, Probleme und Perspektiven. Springer Spektrum, Wiesbaden

Bendorf M (2002) Bedingungen und Mechanismen des Wissenstransfers. Lehr- und Lern-Arrangements für die Kundenberatung in Banken, Dissertation, Uni Göttingen

Bloom BS (1956) Taxonomy of educational objectives, handbook I: Cognitive domain. Longmans Green, New York Bühner M (2011) Einführung in die Test- und Fragebogenkonstruktion, dritte aktualisierte Auflage. Pearson-Studium, München Cattell RB (1961) Culture Free Intelligence Test, Scale 3 (Handbook), 2nd edition. Champaign, III (USA)

Dörner D (1976) Problemlösen als Informationsverarbeitung. Kohlhammer, Stuttgart

Geißel B (2008) Ein Kompetenzmodell für die elektrotechnische Grundbildung: Kriteriumsorientierte Interpretation von Leistungsdaten. In: Nickolaus R, Schanz H (eds) Didaktik der gewerblichen Berufsbildung. Konzeptionelle Entwürfe und empirische Befunde (Diskussion Berufsbildung, vol 9). Schneider Verlag Hohengehren, Baltmannsweiler, pp 121-141

Gross D, Hauger W, Schröder J, Wall WA (2012) Technische Mechanik 3, vol 12. Springer, Berlin, Heidelberg

Gschwendtner T (2008) Ein Kompetenzmodell für die kraftfahrzeugtechnische Grundbildung. In: Nickolaus R, Schanz H (eds) Didaktik der gewerblichen Berufsbildung. Konzeptionelle Entwürfe und empirische Befunde (Diskussion Berufsbildung, vol 9). Schneider Verlag Hohengehren, Baltmannsweiler, pp 103-119

Hartig J (2007) Skalierung und Definition von Kompetenzniveaus. In: Beck B, Klieme E (eds) Sprachliche Kompetenzen. Konzepte und Messung. DESI-Studie (Deutsch Englisch Schülerleistungen International), Beltz, Weinheim, pp 83-99

Hauck C (2012) Vergleich der mathematischen Kompetenzen von Gymnasiasten an allgemein bildenden und technischen Gymnasien in Baden-Württemberg. Master-Thesis, University of Stuttgart, Stuttgart

Hell B, Trapmann S, Schuler H (2007) Eine Metaanalyse der Validität von fachspezifischen Studierfähigkeitstests im deutschsprachigen Raum. Empirische Pädagogik 21(3):251-270

Hindenach, M (2012) Entwicklung eines Eingangstests für physikalisch-technische Kompetenzen zu Beginn des Maschinenbau-Studiums, mit den Bereichen Statik und Dynamik auf Basis von curricularen Analysen in den Schulformen Allgemeinbildendes und Technisches Gymnasium. Master-Thesis, University of Stuttgart, Stuttgart

Jürgens A, Zinn B (2012) Nichttraditionell Studierende in ingenieurwissenschaftlichen Studiengängen - Zugangswege, Motive, kognitive Voraussetzungen. Beiträge zur Hochschulforschung 34(4):34-53

Kauertz A (2008) Schwierigkeitserzeugende Merkmale physikalischer Leistungsaufgaben. Logos, Berlin

Klieme E, Neubrand M, Lüdtke O (2001) Mathematische Grundbildung: Testkonzeption und Ergebnisse. In: Baumert J, Klieme E, Neubrand O, Prenzel M, Schiefele U, Schneider W, Stanat P, Tillmann KJ, Weiß M (eds) PISA 2000. Basiskompetenzen von Schülerinnen und Schülern im internationalen Vergleich. Leske + Budrich, Opladen, pp 139-190

Neumann I et al (2014) Mathematische Eingangsvoraussetzungen von Studierenden der Ingenieurswissenschaften. Talk presented at the 2nd GEBF conference, Frankfurt, 3-5 March 2014

Neumann M, Nagy G, Trautwein U, Lüdtke O (2009) Vergleichbarkeit von Abiturleistungen: Leistungs- und Bewertungsunterschiede zwischen Hamburger und Baden-Württemberger Abiturienten und die Rolle zentraler Abiturprüfungen. Zeitschrift für Erziehungswissenschaft 12:691-714

Nickolaus R, Abele S (2009) Chancen und Grenzen eines differenzierten Ansatzes zur Hochschulbewerberauswahl. In: Das Hochschulwesen. Forum für Hochschulforschung, Praxis und Politik 57(3):81-88

Nickolaus R, Rosendahl J, Gschwendtner T, Geißel B, Straka GA (2010) Erklärungsmodelle zur Kompetenz- und Motivationsentwicklung bei Bankkaufleuten, Kfz-Mechatronikern und Elektronikern. In: Seifried J, Wuttke E, Nickolaus R, Sloane PFE (eds) Lehr-Lern-Forschung in der kaufmännischen Berufsbildung - Ergebnisse und Gestaltungsaufgaben. Steiner, Stuttgart, pp 73-87

Nickolaus R, Lazar A, Norwig K (2011) Assessing Professional Competences and their Development in Vocational Education in Germany - State of Research and Perspectives. In: Bernholt S, Neumann K, Nentwig P (eds) Making it tangible. Learning outcomes in science education. Waxmann, Münster et al., pp 129-150

Nickolaus R, Abele S, Gschwendtner T, Nitzschke A, Greiff S (2012) Fachspezifische Problemlösefähigkeit in gewerblichtechnischen Ausbildungsberufen - Modellierung, erreichte Niveaus und relevante Einflussfaktoren. Zeitschrift für Berufs- und Wirtschaftspädagogik 108(2):243-272

Nickolaus R, Seeber S (2013) Berufliche Kompetenzen: Modellierungen und diagnostische Verfahren. In: Frey A, Lissmann U, Schwarz B (eds) Handbuch berufspädagogischer Diagnostik. Weinheim, Beltz, pp 166-195

Pant HA, Stanat P, Schroeders U, Roppelt A, Siegle T, Pöhlmann C (eds) (2013) IQB-Ländervergleich 2012. Mathematische und naturwissenschaftliche Kompetenzen am Ende der Sekundarstufe I. Waxmann, Münster, New York, München, Berlin

Pittich D (2013) Diagnostik fachlich-methodischer Kompetenzen. Dissertation, TU Darmstadt

Prenzel M et al (1996) Selbstbestimmt motiviertes und interessiertes Lernen in der kaufmännischen Erstausbildung. In: Beck $\mathrm{K}$, Heid H (eds) Lehr-Lern-Prozesse in der kaufmännischen Erstausbildung - Wissenserwerb, Motivierungsgeschehen und Handlungskompetenzen (Zeitschrift für Berufs und Wirtschaftspädagogik - Beiheft). Steiner, Stuttgart, pp 109-127

Rittle-Johnson B, Siegler RS (1998) The relations between conceptual and procedural knowledge in learning mathematics. A review. In: Donland C (ed) The development of mathematical skills. Psychology Press, Hove, pp 75-110

Rumelhart D, Norman D (1981) Analogical Processes in Learning. In: Anderson JR (ed) Cognitives Skills and Their Acquisition. Erlbaum, Hillsdale 
Schmidt-Atzert L, Deter B, Jaeckel S (2004) Prädiktion von Ausbildungserfolg: Allgemeine Intelligenz (g) oder spezifische kognitive Fähigkeiten? Zeitschrift für Personalpsychologie 3:147-158

Schuler H, Hell B (2008) Studierendenauswahl und Studienentscheidung aus eignungsdiagnostischer Sicht. In: Hell B (ed) Schuler H. Studierendenauswahl und Studienentscheidung. Hogrefe, Göttingen, pp 11-17

Schuler H, Höft S (2006) Konstruktorientierte Verfahren der Personalauswahl. In: Schuler H (ed) Lehrbuch der Personalpsychologie, 2nd revised and, extendedth edn. Hogrefe, Göttingen

Seeber S (2008) Ansätze zur Modellierung beruflicher Fachkompetenz in kaufmännischen Ausbildungsberufen. Zeitschrift für Berufs- und Wirtschaftspädagogik (ZBW) 104(1):74-97

Statistisches Bundesamt (2013) Fachserie. 11 Bildung und Kultur. Reihe 4.1 Studierende an Hochschulen. Endgültige Ergebnisse. Wintersemester 2012/2013, Wiesbaden

Stern E (2001) Intelligenz, Wissen, Transfer und der Umgang mit Zeichensystemen. In: Stern E, Guthke J (eds) Perspektiven der Intelligenzforschung. Pabst Science Publishers, Lengerich, pp 163-203

Thunsdorf C, Schmitt M (2013) Berufseignung und Personenmerkmale. In: Schwarz B (ed) Frey A, Lissmann U. Handbuch Berufspädagogischer Diagnostik. Beltz, Weinheim, Basel, pp 126-136

Trapmann S, Hell B, Weigand S, Schuler H (2007) Die Validität von Schulnoten zur Vorhersage des Studienerfolgs - eine Metaanalyse. Zeitschrift für Pädagogische Psychologie 21:11-27

Weiß R, Cattell RB (1971) Grundintelligentest CFT 3 Skala 3. Hogrefe, Göttingen

Zinn B (2012) Ein ingenieurwissenschaftliches Studium von beruflich qualifizierten Studierenden - Chancen und Risiken. Zeitschrift für Berufs- und Wirtschaftspädagogik (ZBW) 108(2):273-290

Submit your manuscript to a SpringerOpen ${ }^{\circ}$ journal and benefit from:

- Convenient online submission

- Rigorous peer review

- Immediate publication on acceptance

- Open access: articles freely available online

- High visibility within the field

- Retaining the copyright to your article

Submit your next manuscript at $>$ springeropen.com 